\title{
My Memories of Russell Hamilton
}

\author{
LUÍS BERNARDO HONWANA \\ Writer, Former UNESCO Diplomat, \\ Executive Diretor, BioFund Mozambique
}

I met Russell Hamilton shortly after I arrived in Lisbon in the early 1970s. This was my first voyage outside of Africa.

I was forced to leave Mozambique because the Portuguese Secret Police (PIDE) were threatening to arrest me again, just two years after I was released from prison, where I had served a 3-year term for anti-colonial activity. My work as a journalist and my social stance were still regarded as "subversive" in the tense atmosphere of what was then Lourenço Marques.

A providential scholarship from the Calouste Gulbenkian Foundation, thanks to the sponsorship of a lawyer friend, allowed me to go to Portugal to study law at the University of Lisbon. In the past, I had been barred by the colonial regime from travelling outside Mozambique.

I arrived in Portugal without any particular interest in taking a law degree. I wasn't enthusiastic about studying law, but I was anxious to enjoy what the somewhat freer academic environment of Lisbon could provide - in languages, philosophy, history or modern literatures, for example.

My Gulbenkian scholarship sponsor was the Angolan poet, Mário António. He introduced me to the writer Manuel Ferreira, and we began to meet regularly at a café on Avenida de Berna.

It was also through Mário António that I met Russell Hamilton, who was conducting research in Portuguese libraries and archives for what would become his monumental Voices from an Empire-one of the pioneering works in the study of Lusophone African literature. He and Cherie and their children were living in an apartment in Oeiras (a Lisbon suburb), and Cherie was doing research for her excellent book, Cuisines of Portuguese Encounters.

Russell's family and my wife, Suzette, and I rapidly became part of a group in Lisbon, consisting of painters, journalists, people from the theatre, and creative 
spirits in advertising. Aside from the cuisines of the global south and other equally uncontroversial interests, they knew little about Africa and its nascent literatures. A smaller group, however, had more serious debates about African literatures at the table of Mano Ferreira, or "Brother" Ferreira as Russell called him, at the café on Avenida de Berna.

Aside from going to the University and collaborating on newspaper articles and other occasional journalism, I used my time to read voraciously all the publications that were censored or barred from reaching the bookshops in Mozambique-including the many ideological explanations of the Sino-Soviet border dispute of 1969. Despite the ongoing censorship and omnipresence of PIDE in Portugal, there was greater access in Lisbon to all kinds of publications, and debates over ideas were more common than in Mozambique. But it was the discussion about the cultural aspects of the liberation struggles in Africa, and particularly the role of literature, that most excited our group.

Around "Brother" Ferreira's table, we revisited the anti-colonial debates published in Mensagem, the journal of the Casa dos Estudantes do Império. Mensagem had also published an anthology of Mozambican poetry with an introduction by Alfredo Margarido - this was later the subject of a critique by Rui Knopfli. Russell enthusiastically and wholeheartedly engaged in these debates over whether literature transcended the historical realities of the day.

When the moment came for Russell and Cherie to continue their research in Mozambique, I gladly gave them letters of recommendation addressed to such Mozambican luminaries as Eugénio Lisboa, Rui Knopfli, Adrião Rodrigues, José Craveirinha and my own parents, Raúl and Nely Honwana. For me, it was a matter of pride that I was able to facilitate their first visit to Mozambique.

It is not my purpose to tell you everything about my 45-year friendship with Russell Hamilton. Instead, I will focus on how his research advanced the intellectual themes that were most important to him, and how his calm and serene brilliance helped to enrich the lives of those around him.

I would like to thank the organizers for giving me this opportunity to embrace Cherie and allowing me to share, with all of you, this deeply significant moment. I am sure that more qualified voices here today will speak of Professor Hamilton's academic accomplishments. I am here mainly to bring words of nostalgia and gratitude. 
First, I want to express the collective gratitude of all those whose texts from the still scant body of nascent Mozambican literature Russell promoted in Voices from an Empire in those early days when our work was so often ignored. But I am also here to highlight my very personal gratitude for his fraternal interactions and the intellectual stimulus, from which I so benefitted.

What I am going to share now are two or three personal anecdotes, which will give you all some idea of what our long friendship has meant to me.

It is common knowledge that, during the colonial period, when many of us from the Portuguese colonies began to write poetry, fiction or plays, our overarching motivation was the urgent need to express our opposition to colonial oppression, our solidarity with the colonized masses and our affirmation of our otherness - which were more important than the actual quality of what we were producing. This outpouring ranged from the poems that even the leaders of the liberation movements felt obliged to write and leaflet-like texts to the more mature and sculpted compositions, which fortunately also appeared. What defined this literature was its relationship to the sociological realities and the emancipatory process taking place in the territories. While these circumstances disqualified almost our entire literary dawn for many critics, they were highly valued by Russell Hamilton (and some of his contemporaries), who argued that literature could legitimately serve as an affirmation of identity as long as it also satisfied aesthetic and formal requirements.

The coming of age of our literature, which Russell's book acknowledged and celebrated, was infused with the same euphoria of liberation that characterized not only post-independence Mozambique but all the other countries that were former Portuguese colonies.

Russell and Cherie's second visit to Mozambique occurred just after the proclamation of our national independence. The first edition of Voices from an Empire also dates from that magical year of 1975 (strangely enough, when the empire in question ceased to exist). Russell and Cherie were received in Mozambique as important dignitaries. José Craveirinha, who had been their guide on their first visit, in 1971, was appointed their official companion.

Russell and I subsequently met in various countries and continents, often at conferences in which we both participated. And when he added to his schedule an annual visit to Maputo (to select candidates for post-graduate courses in American universities from among the students of Eduardo Mondlane 
University), we began inviting him to our traditional ceremonies, as we did with all honoured guests.

Apart from the pioneering effort of the Sá da Costa publishing house in Lisbon as a promoter of the literary production of the five African countries that use Portuguese as their official language, what made Russell and Cherie's regular visits to each of our countries so memorable was that we learned from them what was happening in the field of arts and letters in Portuguese-speaking Africa as a whole. The isolation of our countries from each other and from the rest of Africa had been one of the weapons of domination used by colonialism. Unfortunately, however, the fall of colonialism did not inevitably lead to our inclusion in the major book distribution circuits - a situation which persists until today.

Over time, several other scholars began to study the African literatures written in the Portuguese language. Some of these scholars, who were Hamilton's contemporaries, are no longer with us. I especially remember Gerald Moser, whom Russell arranged for me to meet at Penn State University on one of my visits to this country, and also "Brother" Ferreira.

A common characteristic of this group of scholars is the role they played in discovering, encouraging and publishing the works of new authors in Portuguesespeaking Africa. Thanks to them, we are no longer in the embarrassing situation of having more anthologies than authors. Instead, our literatures today have a presence on the international stage.

From Russell, we knew not only about what was being produced in the literary "main stream," but also what was taking place on the literary margins, where the most daring and creative projects sometimes emerged.

Although it may appear to negate the idea that one might have of Russell from a reading of his work, I know that he had a special affinity for the ideas of Amiri Baraka (an American), Kaoberdiano Dambara (a Cape Verdean), Amos Tutuola (a Nigerian) and Dambudzo Marechera (a Zimbabwean).

And the interest was not merely in their linguistic innovations, in the formal ruptures, and in the singularities of their narrative structures. We spoke several times about these authors whose provocative writings often overly emphasized the significance of identity, social exclusion and the rebellion of the individual faced with the oppression of the collective-even in situations regarded as revolutionary. These writings reflected the ongoing tension between tradition and 
modernity in an Africa that did not want to dissolve in a neo-colonizing globalization.

I add to my account of the list of literary expressions that merited Russell Hamilton's particular attention the highly controversial poetry of Malangatana, which mixes the naiveté springing from his paintings and a certain dreamlike dimension. He was also attracted to the writings of Paulina Chiziane, who brought into the daily life of her characters the strong presence of the world of the spirits.

It was in this context that we sometimes touched upon themes which, because of the regrettable preconceptions we had inherited from Portuguese colonialism, remained taboo in the Portuguese-speaking African countries. They included the position of the black man in literature; and the importance in our collective imagination of such rituals as candomblé, in Brazil, vodou in Haiti and traditional religions and syncretic practices in Africa and the diaspora.

We agreed that one of the serious sicknesses in our societies - and here I am talking about the space of our common language (i.e. Portuguese) - were the blockages that prevented us from accepting our African-ness.

Thinking today about our conversations about exploitation, I see, on the one hand, an extremely sophisticated, pipe-smoking African-American, with perfect mastery of Brazilian Portuguese who linked his interest in African literatures written in Portuguese with an effort to identify with that which, for want of a better term, we can call African-ness. In the end, this is not a surprising attitude for a member of the diaspora to adopt when given the opportunity to make Africa the theme of his or her life. Unlike the cliché, however, this special African American was not obsessed with the question of his roots. Rather, the mission, as he saw it, was one of helping the African baobab put out branches and bear flowers and fruit.

On the other hand, what I see here is an attraction that we Africans have always had in the reworking by those in the diaspora of our own culture-and in returning to it as a model and a source of inspiration. As in Pan-africanism. As in jazz. And also as in the luminous trajectory of extraordinary figures, such as Russell Hamilton. 